\title{
Women Chewing Gum: Feminist Critical Analysis of Advertising as Symbolic Violence
}

Alparslan Nas

Marmara University Faculty of Communication

alparslan.nas@marmara.edu.tr

\section{Abstract}

Representation of women in advertisements has been a crucial point of debate in critical studies on advertising and gender. Advertising has critically been evaluated as an ideological apparatus that reproduces gender roles and promotes sexism. In addition to overt forms of sexist representations, advertisements also construct implicit meanings of gender inequality, which is difficult to recognize. The aim of this article is to show that advertisements generate "symbolic violence" that normalizes and legitimizes gendered relations of power so that gender inequalities would be misrecognized. Based on Pierre Bourdieu's notion of "symbolic violence", this article analyzes the image of "women chewing gum" in an advertisement campaign by Falım, Turkey's leading chewing gum brand with feminist critical analysis. Falım advertisements portray women who are pressured by patriarchy but do not resist it and are content with it. Eventually, the patriarchal narrative brings forth the normalization of gender inequalities and its communication to the wider public via advertising as a rhetorical device.

Keywords: Advertising, symbolic violence, feminism, gender, male hegemony.

Makale geliș tarihi: 14.09.2015 • Makale kabul tarihi: 12.10 .2015

http://ilefdergisi.org/2015/2/2/

ilef dergisi • ( ) $2015 \cdot 2(2) \cdot$ sonbahar/outumn: 35-54 


\section{Sakız Çiğneyen Kadınlar:}

\section{Simgesel Şiddet Olarak}

\section{Reklamın Feminist}

\section{Eleștirel Analizi}

\section{Alparslan Nas}

\section{Marmara Üniversitesi illetişim Fakültesi}

alparslan.nas@marmara.edu.tr

Öz

Kadın imgesinin reklamlarda temsil biçimleri, reklamlar üzerine eleștirel yaklașımlar kapsamında önemli bir araștırma konusu olagelmiștir. Reklam, toplumsal cinsiyet rolleri ve erkek egemenliğini yeniden üreten bir aygıt olarak eleștirel açıdan sorgulanmıștır. Bu makale, reklamın toplumsal cinsiyetlendirilmiș iktidar ilișkilerini normalleștirmek ve meșrulaștırmak amacıyla kadın üzerinde, Pierre Bourdieu'ya atıfla "simgesel șiddet" uyguladığını ileri sürmektedir. Bu doğrultuda, Türkiye'nin önde gelen sakız markalarından biri olan Falım’ın reklam kampanyasında "sakız çiğneyen kadın" imajı, feminist eleștirel bir analiz ile tartıșılacaktır. Reklamlar erkek egemen baskılara direnç gösteremeyen ve göstermek istemeyen kadın temsilinde bulunmaktadırlar. Kadının baskılardan sıyrılmasını tüketime indirgeyen reklam söylemi, güçlenme illüzyonu yaratmakta ve kadını mağdur eden gerçek koșulları normalleștirmiș olmaktadır. Bu bağlamda etkin olan simgesel șiddet, kadının erkek egemen toplumda karșılaștığı mağduriyet koșullarını görünmez kılmaktadır. Sonuç olarak bu makale, simgesel șiddet ve reklam ilișkisini kavramsallaștırmanın yanında, toplumsal cinsiyetlendirilmiș iktidar ilișkilerini görünür hale getirerek popüler kültürde muhtemel direnç alanlarını mümkün kılabilecek bir feminist eleștirel yaklașımı ortaya koymayı amaçlamaktadır.

Anahtar Kelimeler: Reklam, simgesel șiddet, feminizm, toplumsal cinsiyet, eril iktidar. 
With the advent of consumer cultures all around the globe throughout the twentieth century, advertising has been a crucial tool for communication that mediates between consumers and goods or services. Rapid growth of the markets and diversification of products for different consumer segments brought about the necessity for advertising practices to be symbolically and culturally meaningful. Therefore, rather than serving to the needs of the producers to reach out consumers for sales purposes, advertising managed to attain culturally and symbolically constructed meanings. Exceeding its boundaries solely defined on the basis of economic exchange, advertising has proved itself to be one of the most popular visual artifacts of contemporary society, with its potential not only to simply represent what is out there in society, but also to reproduce certain hegemonic meanings or to construct alternative versions of reality.

Gender has been one of the most popular subjects of advertising since the growth of consumer cultures and the establishment of advertising industry. As a practice of signification, advertisements have represented the images of men and women in different cultural dynamics and related these representations to their goods or services to facilitate consumption. The representation of women in terms of the ways in which femininities have been defined in adverting 
has been a significant point of debate from critical perspectives. Advertising has been widely criticized as a discourse, which reproduces the gendered relations of power and women's subordination resulting from such relations. It has further been considered as a vehicle for legitimizing male hegemony and normalizing women's suppression. Since late the 1990s, reproduction of masculinities also attracted the attention of critical scholarship on advertising and visual culture; in order to shed light on the ways in which hegemonic meanings of masculinity is constructed in representations in popular culture, particularly in advertising. Commercialization and sexualization of male and female bodies were critically debated since the 1990s to point out the deeper structure of meanings that advertising implicitly conveys.

Today, advertising is an important tool of communication that produces and transmits ideologically encoded meanings on gender in more or less subtle formats. Evaluated from a critical point of view, advertisements generally involve discursive formations that construct hegemonic meanings and convey them to the public in an implicit manner, so that they cannot be fully recognized. Advertisements thus represent social reality in a certain manner so that the viewers cannot engage in a critical interrogation of the narrations of power and hegemony that they encounter. From a gendered perspective, advertising is instrumentalized as a patriarchal discourse that generates certain subjectivities to impose particular gender norms on women. Advertising therefore is an important vehicle in Turkey's patriarchal cultural dynamics that practices unique form of violence against women, that is, symbolic violence. Symbolic violence as theorized by Pierre Bourdieu (1984; 2001) is incorporated by the advertising discourse so that the gendered relations of power can be normalized and legitimized in a subtle format.

Basing its analysis on the theoretical propositions put forth by Pierre Bourdieu in his analysis on symbolic violence, this article will critically address the formation and procedure of symbolic violence through the image of "women chewing gum" in a recent advertising campaign in Turkey by Falım brand. Falım is a brand of chewing gum products and is one of the leading companies in the sector. This article will address the operation of symbolic violence through the image of "women chewing gum" in advertisements. The critical analysis will point at the ways in which advertising discourse positions women in subordinate gender roles. It will further stress that women's gender roles are deemed misrecognized by discursive advertising strategies, which leads to the practice of symbolic violence. 


\section{Gendered Critique of Advertising}

The term gender is a useful category to critically negotiate the social and cultural effects of sexual difference. While the notion of "sex" refers to the biological difference between male, female and intersex individuals, the notion of gender points out the cultural and social meanings attributed to sexual difference (West and Zimmerman 1987, p.125). Gender does not point at an achieved status of socially or culturally inscribed sexual difference; it is continuously done by a series of actions on an everyday life basis (West and Zimmerman 1987, p.125). Gender is a set of performances rather than a stable status of affairs (Butler 1999, p.179). Individuals are inclined to perform their gender on the basis of certain behaviors, which are defined as gender roles. The imposition of gender roles generates a disciplinary society, which produces the subjectivities of individuals accordingly, so that individuals can perform the dominant discourses on gender (Pilcher and Whelehan 2004, p.56). The disciplining of gender roles by cultural, social and political institutions results in the emergence of social inequalities and gender hierarchies where male hegemony is practiced. Patriarchal society treats the cultural and social differences between men and women as given and natural, hence it normalizes inequalities. Gender is therefore a useful analytical term for feminist scholarship to point out that differences between men and women are not natural; but rather they occur as a result of cultural and social processes, which tend to reproduce male hegemony.

Gendered relations of power that cause women's subordination is practiced and reproduced by many societal and cultural institutions, including the media and popular culture. Popular representations of female identity in film, television and advertising construct specific images of women with gendered discourses. In this regard, advertising is a crucial apparatus, which widely circulates the gender roles imposed on women, thus enabling the normalization and legitimacy of the hegemonic discourses. Many scholars critically address the role of advertising as a powerful rhetorical tool that manages to consolidate gender roles and sustain gendered relations of power (Williamson 1978; Goffman 1979; Goldman 1992; Jhally 2006). Dyer (1982) considers advertising as a discourse, which sets up the mechanisms of hegemonic meaning distribution and their internalization with the semiotic and discursive mechanisms that it facilitates. Raymond Williams (1999) likened advertising to a cultural tool that produces "magic signifiers" by circulating "idealized" images to ensure that capitalism and consumerism 
can continuously reinvest themselves. According to Williamson (1978), advertising can be considered as an "ideological apparatus", capable of engaging the viewers in a process of identifying themselves with the images that it proposes, in other words, with the idealized versions of reality that reproduce the existing power relations. With a specific focus on gender, Goldman (1992) argues that advertising discourse portrays an image of women as active individuals making her own decisions in so far as she continues to consume in order to seek the ideal beauty and bodily state that is imposed upon her. Goldman suggests that the active and happy image of women in advertisements is only a decoy; its purpose is to conceal the existing gender inequalities and to reduce women's issues to consumption, in a process he defines as "commodity feminism" (1992, p.3).

The representation of women in advertising has different phases. The initial phase is located by feminist scholars as the 1970s, when a critical feminist scholarship emerged focusing on the critical analysis of advertisements (Carter and Steiner 2004, p.2). Until this era, the sphere of popular culture, particularly advertising remained undisputed in terms of gender. Problematizing the representations of women during this period, Goffman observes in the advertisements that women are portrayed as standing lower than men indicating their lower status, conducting child-like gestures, doing housework, becoming an object of male sexual pleasure and spending time in settings such as the kitchen and the bathroom (1979, p.43). Hence the 1970s witnessed the emergence of a critique against the ways in which women were represented in advertising discourse. This helped women to gather a substantial data about sexism in media and further paved the way for locating male hegemonic practices in advertising industry. During this period, feminists challenged the undisputed narratives of advertisements to expose the ways in which male hegemony reproduced its dominance via advertising (Carter and Steiner 2004, p.2). According to them, hegemonic realities with regard to gender roles imposed on women were systematically asserted and naturalized by means advertising discourses (Carter and Steiner 2004, p.3). Therefore, feminist critical scholarship during the 1970s was a counter-hegemonic movement that attempts to uncover the ways in which gendered relations of power operates.

The second phase of the relations are located by feminist scholarship through the late 1980s and the early 1990s, when advertising discourse underwent a transformation mainly in the West. During this period, 
advertisers needed the urge to modify the language of advertising in terms of women's representation due to the mainstreaming of feminist resistance. Accordingly, advertisers tended to reproduce an image of women who is active, powerful and deciding figure (Lazar 2014, p.206). Women's bodies were sexualized and women were portrayed as active, desiring subjects, who constantly attempt to reinvent themselves (McRobbie 2004, p.259; Gill 2007, p.149). Feminist scholars however argued that this particular image of women is problematic in the sense that it brings forth different mechanisms of women's subjection. Imposing the codes of ideal beauty and sexy bodily state, advertising disciplines women's bodies and provide them with the illusion that they are free in so far as they continue consumption (McRobbie 2004; Gill 2007). During the 1990s, the new advertising discourse was an attempt to turn women into surveilled and disciplined subjects who were expected to fill in their lacks by consuming goods. Eventually, a neoliberal form of governing women's bodies and behaviors was accompanied by patriarchal cultural dynamics to reproduce women's subordination. According to Williamson (2003), sexism in this period operated in more subtle and indirect ways, which was very difficult to locate in the advertising discourse. Similarly, Gill claims that this newly emergent advertising discourse makes critique very difficult because it shows the positively connoted narratives on women; systematically conceal the dynamics of women's subordination that lies behind (2009, p.104). As a result, advertising as a discourse is instrumental in rendering gender hierarchies invisible. In this regard, symbolic violence becomes a useful discursive strategy for advertisements to reproduce the existing gendered relations of power and male hegemony.

\section{Advertising and Symbolic Violence}

Violence against women has been one of the most problematic issues of the $20^{\text {th }}$ and the $21^{\text {st }}$ centuries. Many precautions on national and global level have been taken and several policies have been implemented to tackle physical forms of violence, which target women all around the globe. On the other hand, violence may also proceed in symbolic ways rather than mere physicality. The operation of symbolic violence also target women during their lives, especially at domestic sphere and in their workplaces (Morgan and Björkert 2006, p.442-444). Popular culture is another space where symbolic violence is manifest with regard to the gender roles imposed on women. The ways in which "ideal beauty" is encoded by popular culture and imposed on women as a prerequisite of femininity point out the operation of symbolic 
violence on women (McRobbie 2004, p.101). The media and advertising in particular provide a privileged image of women in an idealized state, which systematically excludes the differences among women (McRobbie 2004, p.103). While advertising discourse enforces the idealized images as the norm, it at the same time prevents any critical distance to emerge in the viewers towards such representations. Eventually, it becomes impossible for individuals to engage in a critical interrogation of the images that they encounter to expose the gendered relations of power behind such representations. The ways in which advertising normalizes gendered hierarchies illustrate the operation of symbolic violence as a discursive mechanism.

Bourdieu's notion of symbolic violence paves the way for a critical analysis of popular culture items to discover the relations of power inscribed at the intersections of gender and popular culture (McRobbie 2004, p.104). French sociologist Pierre Bourdieu theorized the concept of symbolic violence in his work "Distinction" (1984) and further elaborated at his later study entitled "Masculine Domination" (2001). The main concern of Bourdieu's social theory is to reveal the mechanisms by which social relations of power and hegemony are reproduced to sustain the established social hierarchies (Nash, 1990). According to Bourdieu, society consists of different fields such as education, family, media, popular culture, etc. to which individuals participate for the purposes of capital accumulation (1993, p.164). These fields are not state-related but autonomous structures with their own dynamics of power that regulates the conflicting interests between the dominating and the dominated (Bourdieu 1993, p.162). The field is the "locus of struggles" (Bourdieu 1975, p.19) activated concomitantly by structure and agency to reproduce or thwart the existing relations of domination. The reproduction of the relations of domination is actualized with the use of symbolic forms of power and violence. For Bourdieu, the characteristic of symbolic power is its "misrecognition"; different than sheer violence, symbolic violence is a specific form of power that attempts to normalize power hierarchies and legitimize domination (Bourdieu 2002, p.140). Symbolic violence operates in such an invisible way that individuals cannot recognize its exposure. The term is different than Gramscian (1971) "consent" since consent refers to the conscious agreement of individuals to a social and political project, whereas symbolic violence refers to a state of affairs where structures of domination are internalized and normalized by social agents. As a result, Bourdieusian approach on symbolic violence forefronts that dominating classes apply symbolic violence on the dominated so that the dominated cannot recognize 
their conditions of subordination and relations of power can be reproduced accordingly.

Gendered relations of power can also be assessed from a symbolic violence perspective, especially with regards to the advertising discourse. According to Bourdieu, masculine domination is one of the subtlest forms of domination due to its application of symbolic violence on women (2001, p.1). Bourdieu questions how gendered relations of power is internalized by women and suggests that male hegemony applies symbolic violence on women so that structures of domination can be normalized, internalized and misrecognized (2001, p.1-2). In his analysis, Bourdieu mainly focuses on the ways in which gendered relations of power are reproduced by male hegemony, without necessarily pointing at how women resist those relations. Although it is problematic to assume women as a homogeneous group submissive to power, Bourdieu's vision is useful to point out the mechanisms of female subordination that are normalized by various strategies in cultural dynamics. As McRobbie (2004) points out, popular culture and particularly advertising can be regarded as one of those strategies designated by discursive mechanisms that tend to normalize women's subordination and legitimize male hegemony. The way in which advertising involves sexist and gendered representations in "subtle" formats as Williamson (2003) suggests, render the advertising discourse as a useful strategy for symbolic violence to be facilitated. In this regard, this article will undertake a critical analysis of a recent advertising campaign by Falım brand in Turkey to illustrate how symbolic violence is established by the advertising discourse. Many scholars have addressed the function of advertising as reproducing the gender roles imposed on women, particularly in cleaning product advertisements (Neuhaus 2011, p.13; Sheehan 2014, p.91). Advertisements regarding household items include more explicit narratives of women's subordination. However, this article will trace the representation of gendered relations of power in a series of advertisements that publicize chewing gums, instead of household products that have traditionally been associated with gendered stereotype of women. Chewing gum advertisements convey more implicit and subtle forms of sexism and gendered hierarchies with the use of symbolic violence as a representational strategy of dominance.

\section{Note on Methodology}

To analyze the ways in which symbolic violence is practiced in advertising discourse, this article will undertake a "feminist critical discourse analysis" (Feminist CDA). Feminist CDA forefronts a political perspective on gender 
and aims to expose and demystify the interplay of power in reproducing gendered discourses (Lazar 2005, p.5). The notion of representation is problematized by feminist CDA in order to highlight the ways in which gendered relations of power are "(re)produced, negotiated and contested in representations of social practices" (Lazar 2005, p.11). According to Lazar, one of the greatest challenges of feminist struggle is the perception that women "have it all" and the assumption that their struggles and accomplishments are a result of personal endeavor; as she considers this as a normative stance, which obscures "the social and material constraints faced by different groups of women" (Lazar 2005, p.18). Feminist CDA therefore aims to uncover the mechanisms of power relations in popular representations of gender from an active feminist critical stance. Feminist CDA is described as a "praxisoriented research" (Lazar 2005, p.6), which aims to expose the misrecognized operations of power establishing itself as natural and legitimate in popular representations (Lazar 2005, p.10).

For this purpose, this article aims to uncover gendered relations of power to expose how symbolic violence is instrumentalized to normalize and legitimize male hegemony. The recent advertising campaign by Falım, a leading chewing gum company in Turkey, is considered as the main research material with its four different advertisements broadcast on TV in 2014 and 2015. The word "Falım" means "my fortune" in Turkish, as the product became widely popular in Turkey for providing fortune-telling messages under its package to consumers. Falım advertisements are important for the demystification of symbolic violence since feminist CDA pays special attention to "the less obvious, nuanced and implicit meanings for the subtle and complex renderings of ideological assumptions and power relations in contemporary societies" (Lazar 2005, p.13). The slogan of the advertisements is "everyday one Falım, my head without stress", as it promises the consumers with the chance of relaxation and relieving of stress with consumption. Advertisements convey this message with female protagonists, who are stressed due to various reasons and who relieve stress by consuming the Falım gum. Women chewing gum are represented as individuals who are liberated from male hegemony. However, representation of women's stress and their relaxation constitutes a highly gendered discourse, which subjects women to symbolic violence. As a result, women's subordination is normalized by advertising discourse and male hegemony is legitimized. 


\section{Analysis of Symbolic Violence in Advertisements}

\section{Advertisement 1: "Cacophony at Home"1}

The first Falm advertisement is entitled "cacophony at home". The event takes place in the living room of a household setting. The initial part of the advertisement represents a woman in the middle with two male children around her. The room is in an untidy condition with all kinds of stuff scattered around. While the woman is busy with ironing, two male children are tugging her at the back. The woman is troubled and seems depressed as she tries to appease the children so that they will not shout at her. In the meantime, children yell at the woman by saying "mom, turn on the television" repeatedly in an aggressive way. Trying to calm down her children, the woman is unable to speak other than a few words that she only whispers "kids". The kids also physically disturb her by touching aggressively so that she would do whatever they want. A few seconds later, the camera focuses on the woman while kids continue yelling at her. She is disturbed and deeply depressed. She turns towards her children and says: "Kids, television, when your dad comes". One of the kids tells her that "we will watch a documentary, ha", once again in an aggressive tone as if he is reprimanding her. The kids continue yelling at her and she gets even more disturbed. At this point, the camera portrays a Fallm chewing gum and the woman opening it up. Amidst the aggressive yelling by the kids, she chews a gum and all of a sudden the yelling of the kids disappears as a sound. She smiles, refreshes herself and manages to relieve all the stress. The final scene display the kids who continue to shout, yet whose yelling turns into a tone of bird singing. In the meantime, the jingle sings the slogan of Falım, stating that "every day one Falım, my head without stress, it writes my fortune, the stress ends".

Falım advertisement bears crucial signifiers in terms of its practice of symbolic violence and the constitution of a discourse on stress. The advertisement constructs a highly patriarchal narrative in the initial scene, which portrays a woman with two kids and doing housework. The patriarchal discourse established in the advertisement reproduce the woman's role as a mother and housewife, whose gender role is assigned to look after the children and do housework. As the advertising discourse establishes the initial stage of gendered relations of power with the spatial organization of the scene, the way kids aggressively shout at the woman enhances the power hierarchies

“Evde Kakafoni" Retrieved online from https:/ / www.youtube.com/watch?v=j0JNypjDPIE 
established between men and women. Male children are represented almost as if they are the copies of their adults; their aggressiveness is an indicator of their acquisition of male hegemonic enculturation, which will further be developed in their future. In a household setting where gendered power hierarchies are strongly established, the kids almost order their mother to turn on the television. In return, she says that the television will be turned on when the father comes. In the meantime, she is busy with ironing, which is another indicator of the gender roles imposed on her, and cannot turn on the television because it is subject to the father's authority. The patriarchal narrative is even more enhanced when the kids, representatives of the father's rule, reprimand their mother in an aggressive tone since she does not obey what they demand. While the advertisement fully establishes the gendered power hierarchies with a series of scenes, the Falım chewing gum appears as "a savior". In a striking way, the woman experiences a totally different emotional state by chewing the gum, relieving her stress and getting out of her depression. While the kids continue their aggressiveness, she behaves in a smiling manner and does not care about the whole of experience of male hegemony. The advertisement promises relaxation for women by chewing a gum; however, what it actually does is to normalize and legitimize male hegemony practiced on women. The discourse of advertising actualizes symbolic violence on woman as she is portrayed as content with her subordination; indifferent to the patriarchal pressure she encounters. What is even more striking is the ending scene when woman continues ironing in a smiling manner while she is chewing a gum. The conduct of ironing, which has traditionally been associated with woman's gender roles, is being continued by the woman who chews the gum. At the point, the gum becomes an instrument by which woman internalizes the gender roles imposed on her without any objection. In sum, the chewing of the gum is proposed as a savior of her problems; yet it merely functions as an apparatus of symbolic violence by which gendered relations of power is rendered misrecognized.

\section{Advertisement 2: "The Boss"2}

The second Falım advertisement is entitled "the Boss". The advertisement narrates an event in an office, with the encounter of a female worker and the male boss. The initial scene portrays a woman entering the office in a hasty way, at the same time saying hello to her colleagues around. In a while she stops as she encounters an elderly male person, who looks towards her in an

2 "Patron" Retrieved online from https:// www.youtube.com/watch?v=yeKhDPilXbo 
aggressive manner. She is disturbed by this encounter since the man is angry with her because of her late arrival. The man asks her, "what time is it Mrs. Selin?" and she does not reply. She tends to utter some words but she cannot, just stands in front of the man in a disturbed manner. The man continues asking and telling her, "what time is it, Mrs. Selin, what time is it? If everyone comes to work late like you, what will happen to this company? This company will crash." The man continues her words in a repeated manner as he constantly says, "this company will crash" as the woman cannot respond. She bows her head, glancing at the man occasionally with a feeling of embarrassment while the man continues yelling her in the middle of the office where other staff are working and seeing the event. Falım gum image is introduced in midst of man's aggressive behavior and the advertisement jingle starts by saying "every day one Falım, my head without stress, it writes my fortune, the stress ends." In the meantime the camera focuses on the woman who consumes a Falım chewing gum. In seconds, she goes through a transformation; she gets relaxed and relieved from her disturbance. The man continues to yell at her but she does not hear. The woman chews the gum while her eyes closed, and when she opens her eyes she sees that the man in front of her transformed into a tiny creature that struggles to yell at her. In his tiny physical state, the man continues asking her about the time, as the woman passes through her in an empowered manner.

The advertisement employs a discursive strategy to show that woman is empowered due to her consumption of a Falım gum. The narrative of empowerment together with the discourse of stress however functions as symbolic violence since it renders the mechanisms of power and male hegemony invisible. The beginning scene of advertisement involves an encounter between a man and a woman. The man is encoded as "the boss", whereas the woman is given the status of a "worker". A classed hierarchy is established in the beginning of the narrative, which is at the same time gendered. The figure of the boss is represented by a man, whereas the figure of the worker is represented by a woman, as the advertisement facilitates the initial mechanisms of gendered power hierarchies. The scene illustrates the ways in which the man, who is associated with "authority", exercises power over the woman, who is accused of being late to work. The man yells at the woman in an aggressive and repeated way, and the woman keeps silent throughout. In the middle of the office where other colleagues are watching her being yelled at, she is represented as a powerless individual who cannot react to and challenge the hegemony imposed on her by man. What happens 
at this point is the intervention of the Falım gum; which appears on the scene as the savior. The appearance of the commodity marks the emancipation of the woman in the discourse of advertising; she opens her eyes in a few seconds and sees that the man has been turned into a tiny creature that cannot exert power on her. What the commodity does is to offer an alternative reality for the woman where gendered relations of power are reversed. However, what actually happens is the application of symbolic violence, which solely offers a fantasy that imaginatively postpones the man's exercise of power on woman. The gum does not challenge male hegemony, but gives the illusion that it can be challenged by chewing a gum; thus exercising symbolic violence. This particular illusion normalizes and legitimizes patriarchy as if it is simple enough to relieve the stress posed by male hegemony only by chewing a gum, without its radical critique. The whole procedure of the discourse of stress established by the advertisement eventually aims at a visual/discursive experience in the viewer so that gendered relations of power would be misrecognized.

\section{Advertisement 3: "The Driver"3}

The third advertisement by Falım represents a scene inside an automobile with a woman and a man. The woman drives the car while the man sits next to her in front. The scene begins with the man saying, "what kind of a car driving is this!" complaining about the driving style of the woman. He seems angry and anxious at the same time. As the scene follows, the woman glances at men occasionally; she is stressed, pressured and disturbed. The man increasingly becomes even more aggressive and repeatedly asks the same question, complaining to the woman. In the middle of this repetition he says, "what kind of a car driving, I don't understand!" as the woman looks towards him in a depressed manner. In the following, the car goes through a quake that disturbs the woman and the man in the automobile. The man gets even angrier as the woman looks at her in a shameful manner, seemingly agreeing that she made a mistake. The man turns towards woman, increases the tone of his voice by saying, "what kind of a car driving is this!" in an aggressive fashion. At this point, the image of Falım chewing gum appears on the screen with the advertisement jingle, "every day one Falım, my head without stress, it writes my fortune, the stress ends". The idea of having a gum comes up to woman's mind and she grabs one to chew. She closes her eyes as she chews the gum; she opens her eyes and looks at the man. The man 
turns into a pixel of random dots, resembling an electronic noise that occur as a result of the lack of transmission signal obtained by the antenna receivers of television sets. He still continues to complain but his voice is not fully heard. The woman sees this transformation, gets initially surprised and soon she steps up gear to drive faster in a triumphant manner.

Falım's "The Driver" advertisement puts forward another visual/ discursive experience in which symbolic violence is instrumentalized by male hegemony against women's subordination. The advertisement starts off with a clearly asserted gender hierarchy: the female driver is being targeted by the male passenger. The gendered stereotype claiming that women cannot drive contrary to men can is constituted as the main gendered discourse in the advertisement. The establishment of gendered hierarchy of power is further strengthened by the ways in which the man treats the female driver for her driving habits. The men repeatedly says that she cannot drive, demotivates her, gets angry at her and makes woman internalize her deed as a blameful act. On the other hand, the woman is silent, she cannot talk and respond to the men's accusations and she is deprived of all the potentials to express her feelings and thoughts. While the man continues his aggressive tone against the woman, the woman discovers Falım gum almost as a "cure" that can heal herself and free her from the stress imposed by the man. As she chews the gum and closes and then opens her eyes for a few seconds, she discovers that the man has turned into a pixel of random dots, voiceless and powerless. The discourse of stress constructed by the advertisement points out the role played by the commodity in ending woman's stress. However, what it actually does is to conceal the real causes of the stress that the woman goes through, that is, the male hegemony and patriarchal pressure. In reality, a commodity such as gum cannot put an end to women's subordination in so far as it does not pose a challenge to the gendered relations of power. However, the advertisement proposes the illusion that women can be liberated from the patriarchal oppression by consumption. This approach exercises symbolic violence on women, whose subordinate position vis-à-vis men's are misrecognized by the discourse of stress conveyed with Falım advertisement.

\section{Advertisement 4: "The Parents' Joy"4}

The last Falım advertisement that will be analyzed in this article is entitled "The Parents' Joy". As the English equivalent of the word, "The Parents' Joy", 
the original expression "mürüvvet" refers to the parents' expectations for their sons or daughters to get married and have children, so that they can see their grandkids during their lifetime. Strongly inscribed within tradition, the word "mürüvvet" is a discourse, which reproduces the heteronormative and gendered idea of the family, in which women's role is defined as the mother with household responsibilities. Differing from the previous advertisements, "mürüvvet" advertisement consists of an interaction between three women. Three women sit on a bank in an outdoor setting, two elderly women and one young woman in the middle. The woman on the left tells the woman on the right that "marry this girl", referring to the young woman sitting in the middle. She continues to say that "her time has come, why does not she marry, marry her, marry her" and repeats her words in a continuous manner. The young woman feels disturbed and pressured and she does not respond to what she is being told. The woman continues, "I am telling you, this girl should get married, marry this girl" as the young woman look at her in an anxious expression on her face. At this point, the image of Falım intervenes to the scene and the advertisement jingle starts: "Every day one Falım, my head without stress, it writes my fortune, the stress ends". The young woman chews the gum, closes her eyes, smiles, opens her eyes and sees that the woman on her left is turned into a balloon flying above, getting distanced from her. While flying away, the woman continues pressuring her about her idea of marriage, telling, "it is time for her to get married, marry this girl Necla". The young woman gets relaxed and smiles as the woman disappears.

The advertisement puts forward a different mechanism of symbolic violence established on a discursive level with its representation of women's dialogue. Although two women are also participating to the dialogue indirectly, it is nevertheless difficult to call this a dialogue because the woman on the left dominates the talk. The advertisement is a typical example of how gendered relations of power are also practiced by women against women and how patriarchy is reproduced among women. Throughout the advertisement, the woman on the left pressures the other woman to marry the young woman sitting in the middle. Entitled by the advertisement as "mürüvvet", a discourse that reproduces the disciplinary gaze of parents on their children, the term provides an ideal space for heteronormativity and patriarchy to police on and regulate youth. Apparently, the young woman does not want to get married and she feels disturbed by the persistence of the woman pressuring her into marriage. She however cannot resist and is powerless to express her emotions and thoughts about a life event that she being pushed into. The commodity of 
the gum, Falım, is introduced once again as a savior of the young woman to get rid of the pressures that she faces. At this point, the advertisement brings along another illusion of empowerment, accomplished by the young woman with consumption. The entrance of the gum into the scene all of a sudden eradicates the problems, reverses the power relations and emancipates the young woman from gendered expectations. Symbolic violence operates at this level in the sense that the conditions that lead to woman's subordination are concealed by means of the emphasis on the commodity and what it promises as "relieving the stress". Conveying the illusion that the commodity eliminates the stress, the advertisement actually reproduces the conditions that may result in women's stress due to male hegemony by reducing the solution of the problems posed by patriarchy to a simple act of consumption.

\section{Conclusion}

This article aimed to uncover the discursive strategies of symbolic violence in Falım advertisements by a feminist critical discourse analysis to expose the ways in which gendered relations of power is established and reproduced. It is observed that the following steps are taken in the process of discourse production with regard to the procedure of symbolic violence:

1. Repetition: Advertising discourse subjects women to repetitive acts practicing patriarchal oppression in a surveilled performance of male hegemony.

2. Commodification and the Illusion of Emancipation: Advertising discourse portrays women as empowered agents who overthrow existing gender hierarchies whenever they consume goods.

3. Misrecognition: Advertising discourse causes the misrecognition of how gendered relations of power operate by rendering the structures of patriarchal oppression invisible and reducing the emancipation of women to a simple act of consumption.

The aim of this feminist critique is to undertake a praxis-oriented research, especially with an attempt to expose the investment of power relations in popular cultural representations, which convey the subtlest formats of gender hierarchies to the rest of the public so that such hierarchies can be normalized and legitimized. During this process, symbolic violence, which attempts at the misrecognition of power relations, is incorporated by the advertising discourse, as a useful tool by which women's subordination can be reproduced and any 
feminist critique can be prevented to become mainstream. As a theoretical elaboration of the ways in which symbolic violence is appropriated as a patriarchal strategy and also as a feminist critique against male hegemonic advertising discourse, this article aimed to reveal how gendered relations of power is discursively constructed in advertisements in subtle formats.

Women in Falım advertisements are chewing gum, which aims to convey to the viewer that they manage to challenge patriarchy. However, what the "women chewing gum" image actually does is to present the illusion that male hegemony is challenged; thus misrecognizing the effects of patriarchal subordination. Representation of women in Falım advertisements is two-fold: first, women are portrayed as passive beings powerless to resist the challenges they encounter. Second, they overcome those challenges by consumption. From a feminist perspective however, women can only overcome the challenges posed by patriarchal oppression with a radical critique of and resistance against gendered relations of power. Contrarily, women in Falım advertisements do not resist; the commodity undertakes the resistance on their behalf. Women keep their silence even after they are "emancipated" by the commodity. Eventually, advertisements themselves function as apparatuses of male hegemony; representing women's subordination resulting from patriarchal oppression as a daily routine experience of "stress" that may easily be overcome by consumption. As this article aimed to show, advertisements serve to the misrecognition of the real causes of gendered relations of power as a problem and their solution, thus carrying out symbolic violence against women. While this article focused on the ways in which a patriarchal discourse is constructed in advertisements for the wider agenda of male hegemony, this particular meaning construction does not necessarily mean that women are passive victims of male hegemonic cultural production. Rather, as active participants of culture, they develop ways to resist such hegemonic representations by contesting and negotiating the meanings constructed by the advertising discourse; which can further be elaborated in another research inspired by feminist theory, methodology and activisms. 


\section{References}

BOURDIEU, P. (1984) Distinction: a social critique of the judgement of taste. London \& New York: Routledge.

BOURDIEU, P. (2002) Language and symbolic power. Cambridge: Polity Press.

BOURDIEU, P. (2001) Masculine domination. Cambridge: Polity Press.

BOURDIEU, P. (1993) The field of cultural production. Columbia University Press.

BOURDIEU, P. (1975) The specificity of the scientific field and the social conditions of the progress of reason. Social Science Information, 14 (6), pp.19-47.

BUTLER, J. (1999) Gender trouble: feminism and the subversion of identity. New York: Routledge.

CARTER, C. and STEINER, L. (2004) Introduction to critical readings: media and gender. In: CARTER, C. and STEINER L. (eds.) Critical readings: media and gender. Oxford: Oxford University Press, pp.1-10.

GILL, R. (2007) Postfeminist media culture: elements of a sensibility. European Journal of Cultural Studies, 10 (2), pp.147-166.

GILL, R. (2009) Supersexualize me! advertising and the midriffs. In: ATWOOD, F. (ed.) Mainstreaming sex: the sexualization of western culture. London \& New York: IB Tauris, pp.93-110.

GOFFMAN, E. (1979) Gender advertisements. New York: Harper Torchbooks.

GOLDMAN, R. (1992) Reading ads socially. London \& New York: Routledge.

GRAMSCI, A. (1971) Selections from the prison notebooks. New York: International Publishers.

JHALLY, S. (2006) Advertising, gender and sex: what's wrong with a little objectification? In: JHALLY, S. (ed.) The spectacle of accumulation: essays in culture, media, \& politics. New York: Peter Lang, pp.163-176.

LAZAR, M. M. (ed.) (2005) Feminist critical discourse analysis: gender, power and ideology in discourse. New York: Palgrave Macmillan.

LAZAR, M. M. (2014) Recuperating feminism, reclaiming femininity: hybrid postfeminist I-dentity in consumer advertisements. Gender and Language, 8 (2), pp.205-224.

MCROBBIE, A. (2004) Postfeminism and popular culture. Feminist Media Studies, 4 (3), pp.255-264.

MORGAN, K. and BJÖRKERT, S. T. (2006) 'I'd rather you'd lay me on the floor and start kicking me': understanding symbolic violence in everyday life. Women's Studies International Forum, 29, pp.441 - 452. 
$54<$ ilef dergisi

NASH, R. (1990) Bourdieu on education and social and cultural reproduction. British Journal of Sociology of Education, 11 (4), pp.431-447.

NEUHAUS, J. (2011) Housework and housewives in American advertising: married to the mop. New York: Palgrave Macmillan.

PILCHER, J. and WHELEHAN, I. (2004) Fifty key concepts in gender studies. London: Sage.

SHEEAN, K. B. (2014) Controversies in contemporary advertising. London: Sage.

WEST, C. and ZIMMERMAN, D. H. (1987) Doing Gender. Gender \& Society, 1(2), pp.125-151.

WILLIAMS, R. (1999) Advertising: the magic system. In: DURING, S. (ed.) The cultural studies reader. London \& New York: Routledge, pp.410-423.

WILLIAMSON, J. (1978) Decoding advertisements: ideology and meaning in advertising. London: Marion Boyars.

WILLIAMSON, J. (2003) Sexism with an alibi. The Guardian. May 31. [Online]. http:/ / www.theguardian.com/media/2003/may/31/advertising.comment [Accessed: 28/08/2015]. 